\title{
Politik Hukum Pembentukan Komisi Kebenaran dan Rekonsiliasi Aceh
}

\author{
Khairil Akbar \\ elkhairi17@gmail.com
}

\begin{abstract}
The signing of Memorandum of Understanding in Helsinki between the Free Aceh Movement (GAM) and the Republic of Indonesia (RI) is a sign of peace for the conflict in Aceh. Among the points of agreement is the establishment of the Truth and Reconciliation Commission (KKR) in Aceh. This study aims to investigate and explain the basis for KKR establishment as well as the concept of Aceh KKR. To answer this, the author uses a juridical-normative approach with the library research method. We find that the formation of KKR in Aceh is based on Article 229 of Law No. 11 of 2006 concerning Aceh Government. However, based on the a quo Law, Aceh KKR is referred to as part of National KKR, while National KKR has yet to be established until today. In addition, the institutional concept of Aceh KKR is independent and non-structural with the aim of strengthening peace, helping to achieve reconciliation between perpetrators of human rights violations and victims, and recommending comprehensive reparation for victims of human rights violations. Aceh KKR is based on Islam, Acehnese, independence, impartiality, non-discrimination, democratization, justice and equality, as well as legal certainty.
\end{abstract}

Keywords: Commission; truth; reconciliation; Aceh; human rights

\begin{abstract}
Abstrak
Penandatanganan MoU di Helsinki antara pihak GAM dan RI merupakan tanda perdamaian konflik Aceh. Di antara butir perjanjian itu ialah dibentuknya KKR di Aceh. Tulisan ini bertujuan untuk menemukan dan menjelaskan apa landasan pembentukan KKR Aceh serta bagaimana konsep KKR Aceh. Untuk menjawab hal tersebut, penulis menggunakan pendekatan yuridis-normatif dengan metode studi kepustakaan (library reaserrach). Tulisan ini menemukan bahwa pembentukan KKR di Aceh didasarkan pada Pasal 229 UU No. 11 Tahun 2006 tentang Pemerintahan Aceh. Hanya saja, berdasarkan UU a quo, KKR Aceh disebut sebagai bagian dari KKR Nasional, sedangkan KKR Nasional belum terbentuk hingga sekarang. Selain itu, ditemukan pula bahwa konsep kelembagaan KKR Aceh bersifat independen dan non-struktural dengan tujuan untuk memperkuat perdamaian, membantu tercapainya rekonsiliasi antara pelaku pelanggaran HAM dengan korban, dan merekomendasikan reparasi menyeluruh bagi korban pelanggaran HAM. KKR Aceh berasaskan keislaman, ke-Aceh-an, independensi, imparsial, non-diskriminasi, demokratisasi, keadilan dan kesetaraan, dan kepastian hukum.
\end{abstract}

Kata-kata Kunci: Komisi; kebenaran; rekonsiliasi; Aceh; HAM 


\section{Pendahuluan}

Aceh semula—sebagaimana daerah lain-merupakan daerah dengan sistem kerajaan. Melihat peta Provinsi Aceh hari ini, maka kerajaan-kerajaan dahulu di wilayah ini banyak jumlahnya. Jika kita menarik sejarah sejak abad pertama Hijriah, di Aceh telah terbentuk kerajaan-kerajaan Islam. Ali Hasjmy menyimpulkan bahwa kerajaan Islam pertama itu adalah kerajaan Peureulak (225 $\mathrm{H}=840 \mathrm{M}$ ), lalu menjalar hingga ke Jaya. ${ }^{1}$ Kondisi Aceh yang terpisah-pisah dan merupakan kerajaan-kerajaan kecil itu pada era berikutnya dianggap terancam. Oleh Ali Mughaiyat, kerajaan-kerajaan itu disatukan dan membentuk kerajaan dengan kekuatan besar. Kerajaan baru ini diberi nama Kerajaan Aceh Darussalam. ${ }^{2}$

Dari kurun waktu yang cukup lama ini, di mana Aceh merupakan pintu masuknya Islam ke nusantara, maka tidak berlebihan sekiranya dikatakan bahwa Islam tidak hanya berakulturasi, melainkan melebur atau berasimilasi dengan Aceh. Menyebut Aceh, kita akan langsung berasumsi tentang Islam, meski Islam tidak hanya dianut oleh bangsa Aceh. Namun, Aceh pastilah beragama Islam. Fanatisme Aceh terhadap Islam ini menjadi semangat yang amat fundamental dalam perjuangan-perjuangan di Aceh. Untuk Islam, nyaris seluruh orang Aceh siap mati. Doktrin ini bahkan selalu dinyanyikan oleh orang tua atau ibu-ibu di Aceh saat mengayun atau meninabobokkan anak-anak mereka. Jika pergi ke Aceh, semboyan senada pasti sering kita temukan terpajang di tempat-tempat tertentu. Bagi orang Aceh, pilihannya hanya ada dua: Udep Saree, Mate Syahid (hidup damai, mati syahid).

Hingga pada masa di mana Aceh memiliki nasib yang hampir sama dengan wilayah lain di Indonesia, Islam tetap menjadi nafas perjuangan mereka. Maka, saat Soekarno meminta Aceh bergabung, Tgk. Daud Beureueh menerimanya karena alasan penyebaran Islam. Logikanya adalah, jika Islam bisa diterapkan untuk daerah yang lebih luas, mengapa mesti mengekslusifkan Islam hanya di Aceh? Pada akhirnya, Aceh yang semula merupakan keresidenan di bawah Provinsi Sumatera Utara, kemudian menjadi provinsi yang dikukuhkan dengan

\footnotetext{
${ }^{1}$ Ali Hasjmy, Kebudayaan Aceh dalam Sejarah, Cetakan I, Penerbit Beuna, Jakarta, 1983, hlm. 44 - 54.

${ }^{2}$ Ibid., hlm. $59-60$.
} 
Keputusan Pemerintah Darurat Republik Indonesia no. 8/Des/W.K.P.H/49, tertanggal 17 Desember 1949. 3 Status ini tidak bertahan lama. Pada rentetan waktu berikutnya, Aceh kembali dilebur menjadi bagian dari Sumatera Utara melalui Perpu No. 5/1950.

Menurut perspektif pusat, kebijakan melebur Aceh menjadi satu keresidenan di bawah Provinsi Sumatera Utara agar Aceh bisa dikendalikan dan lebih baik secara administratif. Namun, harapan itu tidak terwujud. Aceh justru melakukan pemberontakan pada September 1953. ${ }^{4}$ Lumrahnya setiap pergolakan, peperangan, pemberontakan, dan istilah-istilah yang dekat dengan itu, maka perlawanan Aceh kepada NKRI juga menalan banyak korban.

Konflik Aceh dan Indonesia sudah terjadi dua kali sejak Negara Kesatuan Republik Indonesia terbentuk. Masing-masing konflik itu adalah: 1. DI/TII melawan Pemerintah Indonesia (1953 - 1962) dengan tujuan Otonomi; dan 2. Gerakan Aceh Merdeka (GAM) melawan Pemerintah Indonesia (1976 - 2005) dengan tujuan kemerdekaan Aceh. Kedua konflik ini berujung dengan negosiasi yang menghasilkan kesepahaman dan kesepakatan damai. ${ }^{5}$ Sebelum kedua konflik di atas, konflik, bahkan perang memang sudah menjadi tabi'at (kebiasaan) orang Aceh untuk melawan kedhzaliman dan kekafiran. Tidak hanya kepada bangsa lain, sesama orang Aceh juga pernah terjadi perang saudara yakni antara kelompok Ulama yang terafiliasi ke dalam PUSA (Persatuan Ulama Seluruh Aceh) melawan kelompok Ulee Balang (Teuku dan Cut). Peristiwa itu disebut dengan perang Cumbok. ${ }^{6}$

Dapat dikatakan bahwa pemberontakan Aceh terhadap Pemerintah Indonesia pertama kali dilakukan oleh DI/TII yang dipimpin langsung oleh Tgk. Daud Beureueh dan melibatkan banyak orang Aceh. Pemberontakan ini merupakan refleksi dari kekecewaan rakyat Aceh terhadap Jakarta (pusat). Pasca

\footnotetext{
${ }^{3}$ Taufik Adnan Amal dan Samsu Rizal Panggabean, Poitik Syariat Islam, Cetakan I, Pustaka Alvabet, Jakarta 2004, hlm. 21.

${ }^{4}$ Ibid., hlm. $20-21$.

${ }^{5}$ Suadi Zainal, "Transformasi Konflik Acehdan Relasi Sosial -Politik di Era Desentralisasi” artikel dalam MASYARAKAT: Jurnal Sosiologi, Vol. 21, No. 1, Januari 2016, hlm. 81 - 108.

${ }^{6}$ Cumbok adalah nama Desa/Gampoeng di Kecamatan Sakti, Kabupaten Pidie. Dinamai perang Cumbok karena revolusi social itu terjadi di Cumbok, yaitu pada tahun 2015 - 2016. Lihat Heryati, "Ulama dan Ulee Balang: Potret Revolusi Sosial di Aceh Tahun 1945 - 1946”, artikel dalam Jurnal Historia, Vol. 3, No. 2, 2015, hlm. 83 - 89.
} 
DI/TII, Aceh kembali berontak dengan motif yang kurang lebih sama. Kali ini, pemberontakan itu dipimpin oleh Hasan Tiro melalui Gerakan Aceh Merdeka (GAM).7 Sebagai penekanan, peristiwa-peristiwa itu tentu menimbulkan banyak korban dan banyak pelanggaran. Kondisi ini diperparah dengan peristiwa Desember 2004. Aceh diguncang oleh gempa dan dibumiratakan oleh Tsunami. Korban-korban yang berjatuhan, keadaan Aceh yang semakin terpuruk, dan kesadaran akan buruknya perang mengantarkan Aceh pada kesepakatan damai.

Perdamaian mestilah diisi dengan berbagai pembangunan dan pendekatan. Korban-korban yang meninggalkan ahli waris mesti merasakan keadilan dan perlakuan yang baik sebagai buah dari perdamaian. Di antara niat baik itu, mengungkap segala bentuk pelanggaran di masa lalu, spesifiknya adalah pelanggaran HAM, dianggap penting dan menjadi bagian dari kesepakatan damai kala itu. Melalui UU Nomor 11 Tahun 2006 tentang Pemerintahan Aceh, Provinsi ini diberi kewenangan untuk membentuk Pengadilan HAM dan KKR sebagai bagian dari ishlah atau satu sisi subtansial dari suatu perdamaian.

Sekarang, KKR di Aceh sudah ada Qanun dan sudah terpilih pula Komisionernya. Lahirnya Qanun KKR Aceh dan terbentuknya lemabaga ini harus memiliki dasar hukum yang jelas. Selain itu, tujuan lahirnya Qanun dan terbentuknya KKR Aceh harus memiliki tujuan dan alasan yang memadai. Secara garis besar, politik hukum pembentukan KKR di Aceh haruslah terjawab. Politik hukum pembentukan KKR Aceh itu pula yang penulis anggap menarik dan menjadi objek dalam artikel ini. Mengingat bahasan mengenai KKR Aceh sangatlah luas, artikel ini perlu dibatasi oleh rumusan masalah.

\section{Rumusan Masalah}

Berdasarkan uraian di atas, tentunya dengan perspektif politik hukum, penulis hendak menjawab pertanyaan yang penulis ajukan berikut: pertama, apa landasan pembentukan KKR di Aceh (baik historis maupun yuridis)? Kedua, bagaimana konsep KKR di Aceh dan hubungannya dalam sistem hukum Indonesia (perspektif politik hukum)?

\footnotetext{
${ }^{7}$ Husaini Hasan, Dari Rimba Aceh ke Stockhholm, Cetakan I, PT. Batavia Media Utama, Jakarta, 2015.
} 


\section{Tujuan Penelitian}

Berdasarkan pada pertanyaan di atas, maka tulisan ini bertujuan untuk menemukan dan menjelaskan apa landasan pembentukan KKR di Aceh, serta untuk menemukan dan menerangkan bagaimana konsep KKR di Aceh dalam kaitannya dengan sistem hukum Indonesia.

\section{Metode Penelitian}

Untuk menjelaskan rumusan masalah yang diangkat, penulis menggunakan pendekatan yuridis normatif dengan menjadikan Qanun KKR Aceh dan peraturan terakait sebagai objeknya. Sumber data yang digunakan adalah data sekunder yang terbagi menjadi bahan hukum primer dan sekunder. Pengumpulan dan pengolahan data dalam artikel ini menggunakan cara studi kepustakaan, yaitu dengan mengumpulkan bahan-bahan hukum yang ada, menyeleksinya, serta mengklasifikasikan bahan-bahan itu sesuai dengan ruang lingkup dan pokok permasalahan dalam artikel ini.

\section{Hasil Penelitian dan Pembahasan}

\section{Landasan Historis}

Bagian ini akan menerangkan secara historis bagaimana KKR Aceh harus dan akhirnya telah terbentuk. Sebelum meloncat jauh ke peristiwa sejarah, beberapa bulan lalu, yakni ketika di pusat sedang berbicara soal reshuffle kabinet, harian Kompas mengeluarkan artikel yang sedikit banyaknya berbicara soal luka lama yang pernah terjadi di Aceh. Dalam artikel itu, tragedi pembantaian Tengku Bantaqiah disebut-sebut sebagai salah satu peristiwa pelanggaran HAM yang mesti diusut tuntas. Tragedi Jumat berdarah itu meninggalkan sakit mendalam di masyarakat sekitar. Letkol Sudjono dalam kasus ini disinyalir sebagai "otak operasi" malah raib, hilang tanpa jejak. Begitupun dengan pelaku lainnya, masyarakat tidak puas dengan sanksi yang diberikan kepada mereka. ${ }^{8}$

${ }^{8}$ Teuku Kemal Pasha, KKR dan Sisi Lain Luka, Kompas, 27 Juli 2016. 
Pelanggaran HAM di Aceh tidak hanya berbicara soal pembantaian Tengku Bantaqiah di Beutong, Aceh Jaya. Kemal bahkan mengusulkan pengusutan itu ditarik sejauh-jauhnya hingga tragedi Perang Cumbok. Namun, ini hanya usulan. Komnas HAM mencatat setidaknya ada lima kasus pelanggaran HAM di Aceh. Lima kasus itu adalah ${ }^{9}$ peristiwa Rumoh Geudong di Pidie, pembunuhan massal di Simpang KKA Aceh Utara dan Bumi Flora Aceh Timur. Serta penghilangan orang secara paksa dan kuburan massal di Bener Meriah dan pembantaian massal Jambo Keupok. Dari lima kasus itu, tiga diantaranya sudah pernah diselidiki Komnas HAM yaitu Rumoh Geudong, Simpang KKA dan Bumi Flora. Sayangnya, tidak satupun dari berbagai kasus itu yang diadili di pengadilan HAM.

Sebagai gambaran, satu dari sekian model pelanggaran HAM itu, Komnas HAM menemukan seorang korban perempuan dalam kasus Rumoh Geudong di Pidie. Menurut Asri, korban ditangkap karena kakaknya dianggap sebagai anggota gerakan pengacau keamanan (GPK, di Aceh disebut GAM). Ironisnya, sang korban ditangkap dan diperkosa berulang kali bahkan payudaranya dipotong. Menurutnya, kasus Rumoh Geudong baru terbongkar ketika Komnas HAM melakukan investigasi tak lama usai DOM dicabut tahun 1998. Kemudian, Rumoh Gedong terbakar.10 Fakta sejarah inilah yang kemudian diangkat dalam perundingan. Diyakini kala itu bahwa ketidakadilan, lebih tepatnya ketidakmauan pusat (Jakarta/RI) mengadili pelaku pelanggaran HAM berat yang terjadi selama DOM dan pasca 1998 merupakan salah satu sumber dari sekian alasan kekecewaan Aceh terhadap pusat.11

\section{Landasan Yuridis}

Secara singkat, kita dapat mengatakan bahwa pembentukan KKR di Aceh dilandaskan pada UU Nomor 11 Tahun 2016 tentang Pemerintahan Aceh. UU ini sendiri lahir pasca penandatanganan MoU Helsingki. Dalam UU inilah secara tegas diinstruksikan pembentukan Komisi Kebenaran dan Rekonsiliasi di Aceh.12 Pasal

9 "Komnas HAM Selidiki Pelanggaran HAM di Aceh, http://www.hukumonline.com/ diakses pada tanggal 1 Agustus 2016.

${ }^{10}$ Ibid.

11 Ikrar Nusa Bakti, Beranda Perdamaian Tiga Tabun pasca MoU Helsinki, Cetakan I Pustaka Pelajar, Yogyakarta, 2008, hlm. 16.

${ }^{12}$ Lihat Abraham Utama, Jalan terjal Pengesahan Qanun KKR di Aceh, (Koleksi Pusat Dokumentasi Elsam). 
229 UU a quo menyebutkan bahwa untuk mencari kebenaran dan rekonsiliasi, dengan undang-undang ini dibentuk Komisi Kebenaran dan Rekonsiliasi di Aceh. Pada Pasal 230 disebutkan bahwa ketentuan lebih lanjut terkait dengan pelaksanaan pemilihan, penetapan, anggota organisasi dan tata kerja, masa tugas, dan biaya penyelenggaraan KKR akan diatur dengan Qanun Aceh, tentunya dengan memerhatikan peraturan perundang-undangan.

Qanun Aceh tentang KKR masuk kedalam rancangan Qanun yang menjadi prioritas pada 2008..$^{13}$ Namun, perjalanannya menimbulkan banyak persoalan. Pada 2013 akhirnya Qanun KKR disahkan oleh Gubernur Aceh, Zaini Abdullah. Qanun Aceh Nomor 17 Tahun 2013 tentang Komisi Kebenaran dan Rekonsiliasi ini terdiri dari 50 pasal. Qanun ini menjadi legal standing terhadap penyelenggaraan KKR di Aceh. Qanun ini sangat fleksibel dan akan menyesuaikan diri dengan UU KKR nasional jika nantinya terbentuk. Sementara itu, UU Nomor 11 Tahun 2006 sebenarnya malah menghendaki terbentuknya KKR Indonesia terlebih dahulu baru kemudian dibentuk KKR Aceh. Sebab dalam UU a quo disebutkan bahwa KKR Aceh merupakan bagian yang tidak terpisahkan dari KKR Nasional (Indonesia).

Kenyataan demikian ini menurut penulis merupakan kerancuan yang disengaja. Ketika di level nasional pasal-pasal KKR itu dibabat habis hingga dibatalkannya UU KKR oleh MK, lalu berdampak pada terhambatnya proses pengungkapan luka masa lalu. Jika mengikuti pola pembentukan KKR sebagaimana yang diamanatkan oleh UU Nomor 11 Tahun 2006, maka KKR Aceh mesti menunggu terbentuknya KKR Nasional. Hal ini sangat mungkin sebenarnya, mengingat UU KKR terlebih dahulu ada dibanding UU Pemerintah Aceh. Namun UU KKR itu dibatalkan dan dinyatakan bertentangan oleh MK. Secara filosofis, pembatalan itu seakan menciderai semangat menegakkan prinsip kemanusiaan yang adil dan beradab. Sebab, dengan membiarkan pelanggaran, berarti negara membiarkan perilaku yang tidak beradab itu terjadi.

${ }^{13}$ Ikrar Nusa Bakti, Beranda Perdamaia..., Op. Cit., hlm. 303. 


\section{Konsep KKR Aceh}

KKR Aceh merupakan bagian dari perdamaian (butir 2.3 MoU antara GAM dan RI). Perdamaian 15 Agustus 2005 itu disusun atas dasar kesadaran para pihak untuk menciptakan Aceh yang berkemanusiaan, adil, dan demokratis. ${ }^{14}$ Hal ini menjelaskan kepada bahwa pembentukan KKR mesti dimaknai sebagai kesepakatan antara pihak yang berkonflik. Dengan begitu, bagaimana konsep KKR juga mesti diasumsikan sebagai konsep yang disepakati, tidak berat sebelah, dan sejalan dengan tujuan dari pembentukannya.

Kerja-kerja KKR Aceh terfokus pada upaya untuk pemenuhan hak-hak korban atas kebenaran agar terlindunginya hak korban dan keluarganya sesuai dengan kebutuhan dan harapan korban. Konsep yang dibangun lebih kepada pengungkapan fakta, bukan sekadar dugaan atas fakta. ${ }^{15}$ Pengungkapan kebenaran itu didasarkan pada integritas, jujur, dan tidak boleh menutupi isu tertentu meski sangat sensitif.

Pasal 2 Qanun Aceh Nomor 17 Tahun 2013 tentang KKR menyebutkan bahwa KKR Aceh berasaskan keislaman, ke-Aceh-an, independensi, imparsial, nondiskriminasi, demokratisasi, keadilan dan kesetaraan, dan kepastian hukum. Dengan memperhatikan asas-asas itu, KKR Aceh diharapkan mampu menggapai tujuan kerjanya. Adapun tujuan KKR Aceh dibentuk (sesuai Pasal 3) adalah:16

a. Memperkuat perdamaian dengan mengungkapkan kebenaran terhadap pelanggaran HAM yang terjadi di masa lalu.

b. Membantu tercapainya rekonsiliasi antara pelaku pelanggaran HAM baik individu maupun lembaga dengan korban; dan

c. Merekomendasikan reparasi menyeluruh bagi korban pelanggaran HAM, sesuai dengan standar universal yang berkaitan dengan hak-hak korban.

Kelembagaan KKR Aceh bersifat independen dan non-struktural. Dengan jumlah tujuh orang Komisioner, KKR Aceh dipimpin oleh satu orang ketua dan satu orang wakil saja. Ketua dan wakil merangkap sebagai anggota bersama lima komisioner lainnya. Mereka-mereka ini dipilih oleh DPRA dan ditetapkan oleh

${ }^{14}$ Haris Azhar, Geunap Aceh: Perdamaian Bukan Tanda tangan (Prospek Hukum KKR Aceh), Cetakan I, Aceh Institut Press, Banda Aceh, 2010, hlm. 93.

${ }^{15}$ Hendra Budiman, Geunap Aceb: Perdamaian Bukan Tanda tangan (KKR dan Penyelesaian Masalah HAM), Cetakan I, Aceh Institut Press, Banda Aceh, 2010, hlm. 95.

${ }^{16}$ Lihat Pasal 3 huruf a, b, dan c Qanun Aceh Nomor 17 Tahun 2013 tentang Komisi Kebenaran dan Rekonsiliasi Aceh. Lembaran Aceh Tahun 2013 Nomor 17. 
Gubernur. KKR Aceh berkedudukan di ibu kota Provinsi (Banda Aceh). Lembaga ini bisa bekerja sama dengan NGO dan pemerintah.

\section{Tugas dan Fungsi KKR Aceh}

KKR Aceh ini nantinya akan dibantu oleh kempok kerja. Ada enam kelompok yang masing-masing terdiri dari dua hingga enam anggota. Satu di antara anggota itu mesti perwakilan dan anggota KKR, sedangkan anggota lainnya berasal dari luar KKR. Enam kelompok kerja itu membidangi tugas pengungkapan kebenaran, perempuan, reparasi, perlindungan saksi dan korban, dokumentasi dan publikasi, dan bidang Rekonsiliasi. Dengan bidang kerja yang demikian itu, KKR Aceh bertugas: ${ }^{17}$

a. menyusun mekanisme pengungkapan kebenaran, reparasi dan rekonsiliasi;

b. mengumpulkan informasi dari organisasi pemerintah dan organisasi non pemerintah baik nasional maupun internasional, yang dilakukan atas inisiatif organisasi tersebut ataupun permintaan KKR Aceh sepanjang masih dalam lingkup kompetensi KKR Aceh;

c. melakukan penyelidikan untuk mencapai tujuannya termasuk mendapatkan laporan-laporan, dokumen-dokumen, atau bukti-bukti dari pihak berwenang dan badan pemerintah;

d. menerima pernyataan dan bukti lainnya dari para korban, perwakilan, ahli waris atau kerabat korban;

e. bertanggung jawab menjaga kerahasiaan orang yang melapor dan memberikan kesaksian;

f. memberikan perlindungan kepada saksi dan korban serta orang-orang yang terlibat dalam proses pengungkapan kebenaran, apabila dibutuhkan;

g. menjaga arsip-arsip yang berkaitan dengan pelanggaran HAM untuk mencegah penyalahgunaan dan penghancuran arsip-arsip dan/atau barang bukti lainnya;

h. melaporkan temuan tentang pelanggaran HAM dan dugaan pelanggaran HAM berat, berdasarkan bukti da fakta yang telah dikumpulkan, termasuk analisis faktor penyebab dan peristiwa yang melatarbelakangi, motivasi politik dan/atau ekonomi, tindakan dan aktor baik lembaga negara maupun non-negara serta dampaknya; dan

i. menyampaikan laporan akhir kepada pemerintah Aceh, DPRA, Pemerintah, lembaga-lembaga penegakan HAM dan publik.

17 Lihat Pasal 8 Qamun Aceh Nomor 17 Tahun 2013 tentang Komisi Kebenaran dan Rekonsiliasi Aceh. Lembaran Aceh Tahun 2013 Nomor 17. 
Dalam hal pengungkapan kebenaran, KKR Aceh dapat mengungkap segala bentuk pelanggaran HAM bahkan di luar Aceh selagi memiliki keterkaitan dengan pelanggaran HAM di Aceh. Sedangkan dari sisi waktu, pengungkapan kebenaran memiliki dua prioritas. Pertama mesti mengungkap kejadian 1976 hingga 2005. Setelah itu, kemudian mengungkap kasus-kasus di bawah 1976.18 Dengan demikian, apa yang ditawarkan Teuku Kemal Pasha (sebagaimana telah disinggung di awal) akan terakomodir.

Untuk menjalankan tugas-tugas itu, KKR Aceh mesti benar-benar menjalankan fungsinya seperti berpegang pada prinsip, membuat kebijakan serta rencana yang berkaitan dengan semua bidang KKR, berkoordinasi, membangun jaringan, dan memastikan ketersediaan sumber daya untuk mengontrol anggaran yang berkaitan dengan penyelenggaran KKR itu sendiri.

\section{KKR Aceh dan Hubungannya dengan Sistem Hukum Indonesia}

UU Nomor 11 Tahun 2006 tentang Pemerintahan Aceh menyebutkan dengan jelas bahwa KKR Aceh merupakan bagian dari KKR Nasional. Lebih lanjut, KKR Aceh disebut bekerja berdasarkan peraturan perundang-undangan. Sebagaimana dalam penjelasan Pasal 229 ayat (3) UU tersebut mengatakan bahwa peraturan perundang-undangan yang dimaksud adalah UU Nomor 27 Tahun 2004 tentang Komisi Kebenaran dan Rekonsiliasi. Memahami dengan jeli bunyi pasal ini, maka kita dapat menggambarkan bahwa KKR Aceh baru akan terbentuk jika KKR Nasional telah ada. ${ }^{19}$ Dalam rancangan semula, pembentukan KKR Aceh memang demikian pengaturannya. KKR Aceh akan dimulai dengan terlebih dahulu membentuk KKR Nasional. DPR RI lantas mengesahkan UU KKR nasional yang tercantum dalam UU No. 27 Tahun 2004 tentang Komisi Kebenaran dan Rekonsiliasi. Namun, UU ini diuji ke Mahkamah Kontitusi (MK).

Pengujian UU KKR di MK (judicial review) mengakibatkan UU tersebut dicabut seluruhnya. Hal ini diseabkan karena pasal yang dicabut adalah pasal jantung. Jimly menegaskan hal ini dengan menyebut bahwa pasal yang diuji berbicara soal amnesty. Pasal tersebut merupakan pasal jantung yang akan

${ }^{18}$ Lihat Bab V, Pengungkapan Kebenaran Bagian Pertama, Pasal 19 ayat (1) hingga (4) Qanun Aceh Nomor 17 Tahun 2013 Tentang Komisi Kebenaran dan Rekonsiliasi Aceh. Lembaran Aceh Tahun 2013 Nomor 17.

${ }^{19}$ Hendra Budiman, Geunap Aceb: Perdamaian Bukan Tanda tangan (KKR... Op. Cit., .hlm. 98. 
berpengaruh pada pasal-pasal lainnya. Dari situlah UU KKR akhirnya dicabut keseluruhannya. ${ }^{20}$

Pasca dicabutnya UU KKR, KKR Aceh masih berharap UU KKR kembali dirumuskan. Hal ini terlihat dari keterhubungan atau lebih tepatnya ketergantungan KKR Aceh pada KKR Nasional sebagaimana tertuang dalam Qanun Aceh Nomor 17 Tahun 2013 tentang KKR Aceh. Pasal 48 ayat (4) Qanun ini menyebutkan “Dengan terbentuknya Undang-Undang Republik Indonesia tentang Komisi Kebenaran dan Rekonsiliasi, tata kerja KKR Aceh akan disesuaikan kembali". Pasal tersebut secara terbuka menjelaskan bahwa KKR Aceh akan disesuikan dengan KKR Nasional. Pemahaman optimis dari regulasi seperti ini adalah, peraturan sebagaimana disebut tadi bertujuan untuk keteraturan, sinkronisasi, mempermudah segala proses, serta memperkuat posisi KKR Aceh itu sendiri.

Mengingat keterhubungan yang penulis gambarkan di atas, maka ada dua kemungkinan yang sedang terjadi. Pertama, apakah pemahaman demikian itu tidak benar, atau kedua bahwa telah terjadi pelanggaran prosedural yang berdampak pada ketidaktertataannya sistem hukum kita. Asumsi pertama dapat kita terima dengan alasan bahwa KKR Aceh yang kerjanya dilandaskan pada peraturan perundangundangan itu, diubah penafsirannya dan dikembalikan pada definisi peraturan perundang-undangan dalam UU Nomor 10 Tahun 2004 sebagaimana telah diubah dengan UU Nomor 12 Tahun 2011.21 Artinya, Qanun bisa membentuk KKR berdasarkan pemeahaman ini, sebab Qanun (perda) bagian dari peraturan perundang-undangan. Namun, pemahaman seperti ini juga memiliki banyak titik lemah. Sejak awal, persoalan KKR memang diatur secara semberono dan jauh dari kata serius.

\section{Antara Harapan dan Kerancuan}

Ditinjau dari sisi harapan, apa lagi ketika KKR didefiniskan sebagai medium pengungkapan kebenaran, benar bahwa KKR bernilai strategis bagi Aceh. Fajran 2016.

20 "Terhambatnya Pembentukan KKR di Aceh", http://www.idlo.int/ diakses pada tanggal 4 Agustus

${ }^{21}$ Haris Azhar, Geunap Aceh: Perdamaian..., Op. Cit., hlm. 94. 
Zein (salah seorang Komisioner KKRA) menyebutnya sebagai babak penting dari proses menuju rekonsiliasi total. ${ }^{22}$ Dari situ, Ia menganggap bahwa aspek politik (yang disinyalir sebagai hambatan) mesti dikesampingkan terlebih dahulu. Fajran menganggap bahwa aspek kemanusiaanlah yang mestinya dikedepankan dan memang tidak mungkin menunggu lama. ${ }^{23}$

Tahun 2013 lalu, harapan-harapan itu mendapat anginsegar. KKR Aceh telah dibentuk. Tapi, terbentuknya KKR Aceh memunculkan banyak kerancuan. Jika di awal penulis hanya menyebut beberapa aturan mengenai pembentukan KKR di Aceh, maka kali ini peraturan itu dikritik agar ditemukan jalan keluarnya. Sebagaimana sempat disinggung, berikut beberapa kerancuan yang penulis temukan dari upaya menulis paper ini:

1. Pasal 229 ayat (2) UU Nomor 11 Tahun 2006 menyebutkan bahwa KKR Aceh merupakan bagian yang tidak terpisahkan dari KKR Nasional. Nyatanya, KKR Nasional saja belum terbentuk. Lebih parah dari itu, UU KKR yang ada sudah dicabut sedangkan yang baru belum juga menyusul.

2. Pada ayat (3) pasal dan UU yang sama dikatakan bahwa KKR Aceh bekerja berdasarkan peraturan perundang-undangan. Pada bagian penjelasan, peraturan yang dimaksud adalah sesuai UU Nomor 27 Tahun 2004. Masalahnya, UU ini dibatalkan oleh MK tahun 2006 beberapa bulan setelah UU Nomor 11 Tahun 2006 disahkan. Pertanyaannya, bagaimana kemudian KKR Aceh bisa dibentuk dan direalisasikan? Nah, di sini terlihat jelas tidak komitmennya pemerintah dalam hal ini.

3. Qanun KKR Aceh telah terbentuk dengan landasan Pasal 230 UU Nomor 11 Tahun 2006. Qanun berdasarkan pasal ini semestinya hanya mengatur soal pemilihan, penetapan anggota, organisasi dan tata kerja, masa tugas, dan biaya penyelenggaraan KKR Aceh saja. Faktanya, Qanun KKR Aceh ini malah berbicara hingga tugas, fungsi, serta kewenangan KKR Aceh. Jika fakta ini ditolak dengan mengatakan bahwa Qanun KKR tidak melebihi kewenangan yang diberi oleh Pasal 30 UUPA, maka KKR Aceh belum bisa bekerja, sebab mandatnya ada pada Pasal 229 UUPA. 
4. Pasal 48 ayat (4) Qanun KKR Aceh sepertinya hanya sementara dan sekadar mengisi kekosongan belaka. Hal ini kiranya akan berbenturan dengan tujuan hukum dalam hal menjamin kepastian. Qanun ini malah menyatakan siap untuk direvisi atau dengan kata lain akan mengikuti UU KKR Nasional (atau nama lain) jika terbentuk. Ini memang konsekuensi yang sejak awal KKR Aceh itu memang didesign sebagai sub dari KKR Naional.

\section{Prospek KKR Aceh Kedepan}

Pengadilan HAM pada kasus di Timor Leste yang gagal, sepantasnya kita jadikan pelajaran untuk mengevaluasi langkah-langkah kedepan. Meski banyak kerancuan, harapannya tetap agar perdamaian di Aceh berdampak pada pembangunan yang berkelanjutan. Sejauh ini, memang perkembangan ke arah yang lebih baik dalam pengungkapan kebenaran dan rekonsiliasi sepertinya masih berjalan sebelah kaki. Pusat dalam hal ini Pemerintah RI terkesan kurang serius. Meski demikian, isu terpilihnya beberapa orang sebagai Komisioner KKR Aceh diharap menjadi bantahan akan pesimisme itu.

Dalam Rancangan UU KKR nasional yang diajukan oleh Departemen Hukum dan HAM tidak menyebutkan secara spesifik tentang Aceh. Artinya, KKR yang dibentuk nanti akan bekerja secara menyeluruh untuk seluruh kasus-kasus pelanggaran HAM yang terjadi di Indonesia. Hal ini yang membedakannya dengan UU No. 27 Tahun 2004 yang secara tegas menyebutkan adanya KKR Nasional dan KKR Aceh. Oleh karena itu, Aceh memiliki peluang untuk membuat tugas KKR lebih spesifik. Dengan Qanun itu, KKR Aceh nantinya akan semakin bersinergi dengan pusat. ${ }^{24}$

Mengingat beberapa kerancuan yang penulis paparkan, hal itu juga perlu dicari jalan keluarnya. Isu KKR ini nantinya akan menjadi isu sensitif dan mengundang banyak perhatian. Dengan begini KKR Aceh mesti dimaknai sebagai komitmen menjaga tujuan nasional dan sesuai falsafah bangsa Indonesia. Dengan lembaga ini, kita sebenarnya sedang berkomimen untuk menegakkan demokrasi

24 "Terhambatnya Pembentukan KKR di Aceh", http://www.idlo.int/ diakses pada tanggal 4 Agustus 2016. 
yang sedang berbenah, serta memperjuangkan tegaknya HAM sebagai ciri dari negara maju. Kita juga terus mendorong agar regulasi KKR baik di Aceh maupun nasional terus berbenah hingga mencerminkan hukum yang rasional, transparan, demokratis, responsif terhadap perkembangan ekspektasi masyarakat. ${ }^{25}$

\section{KKR dan Islam}

Pada bagian awal tulisan ini, sudah disinggung soal semangat juang orang Aceh yang berlandaskan pada Islam. KKR Aceh sebagai model baru dalam penyelesaian pelanggaran HAM di Aceh tentu akan disesuaikan dengan Islam. Teorinya Hazairin soal hukum Islam di Indonesia lebih cocok dan kontekstual jika kita melirik Aceh sebagai objek penelitian. Apa pun yang berasal dari dalam (adat misalnya), juga berasal dari luar (seperti produk ijtihadiah dari nalar manusia) akan dicocokkan terlebih dahulu dengan nilai-nilai yang terdapat dalam al-Quran dan Sunnah. Sedangkan adat, agak lebih longgar penerimaannya sebab sudah berasimilasi dengan Islam. Orang Aceh sulit membedakan apakah adat tertentu yang berkembang di masyarakat berasal dari Islam atau adat yang diterima oleh Islam. Hal ini juga sesuai dengan asas keislaman (huruf a) dalam Qanun KKR.

Untuk melihat itu, perlu dijelaskan terlebih dahulu bagaimana pelanggaran HAM dari kaca mata Islam. Secara sederhana, kata fitrah lebih tepat untuk menggantikan istilah HAM yang berakar dari filsafat kebebasan Barat. Pelanggaran terhadap fitrah di dalamnya secara otomatis mengandung makna dilanggarnya hak-hak dasar manusia. Berbeda dengan pelanggaran HAM, terkadang hal-hal yang sifatnya fitrah tidak diperhatikan. Maka dari itu, istilah ini lebih penulis setujui. Terlepas dari penggunaan istilah itu, apa yang terjadi di era konflik dapat kita pastikan juga dilarang dalam Islam. Untuk itu, mesti ada proses yang memulihkan keadaan-keadaan demikian; apakah melalui mekanisme hukum atau ajudikasi seperti KKR ini?

Apa-apa yang tertera dalam UU Perlindungan HAM, seluruhnya menjadi tujuan dari hukum Islam. Sebagai contoh, hak untuk hidup. Hal ini amat dijaga dan diberi fasilitas terhadap keberlangsungannya dengan berbagai instrument

${ }^{25}$ Imam Syaukani dan A. Ahsin Thohari, Dasar-dasar Politik. Hukum, Cetakan Keenam, PT. Raja Grafindo Persada, Jakarta, 2010, hlm. 72. 
hukum. ${ }^{26}$ Penegakan qishash dalam al-Quran jika manusia berpikir tentu akan mencegah mereka dari perbuatan menghilangkan nyawa seseorang, apa pun alasannya. Hanya saja, kecondongan suatu pelanggaran mesti diadili berdasarkan hukum yang sah. Sedangkan KKR bukan pengadilan. KKR lebih kepada pengungkapan fakta saja. Jika tahapan itu berhenti, tentu menjadi persoalan. Kekhawatiran itu sebenarnya sudah terjawab dengan UU Pengadilan HAM. Qanun KKR Aceh juga menyebutkan bahwa pelanggaran berat HAM bisa ditindaklanjuti melaui mekanisme hukum. Tapi, berangkat pada kasus Timor Leste, Pengadilan HAM sepertinya tidak memberi solusi. Pelaku kejahatan HAM justru bebas.

Konsep KKR Aceh merupakan hal baru di Aceh. Sebelumnya, segala bentuk pelanggaran dan kejahatan dilakukan lewat mekanisme peradilan dan adat saja. Dalam hal-hal seperti ini, Islam juga tidak memberi model baku dalam penyelesaian perkara. Sejauh tidak merusak prinsip-prinsip dasar, maka modelmodel baru dapat diterima. Lagi pula, hal ini bukan perkara ibadah khusus. Prinsip dasar dari sesuatu yang non-ibadah ini adalah boleh dilakukan sejauh tidak ada larangan. KKR Aceh dapat diterima sejauh tidak melanggar ketentuan-ketentuan dalam Islam.

Sebagai Komisi yang bertujuan merekonsiliasi dan mengungkap kebenaran, maka jelas bagi kita bahwa Islam juga memberi perhatian terhadap hal itu. Ada ayat yang mengatakan bahwa kita adalah saudara. Dari situ, maka mesti ada rekonsiliasi (ishlah) jika terjadi perselisihan. Kalau menarik mengapa ayat itu turun, maka kejadiannya hampir sama dengan pertikaian antara RI dan GAM. Dengan kesadaran bahwa kita saudara, maka sebaiknya berbaikan. Jadi, proses rekonsiliasi itu sendiri pernah terjadi antara satu kelompok muslim dengan lainnya di masa Nabi.

KKR Aceh kiranya sejalan dengan tuntunan agama di atas. Jauh dari pada itu, dapat dikatakan bahwa KKR merupakan tafsir konkret sebagaimana sekolah menjadi manifetasi dari perintah belajar. Hanya saja, jika KKR ini menutup-nutupi

${ }^{26}$ Lihat Jasser Auda, Membumikan Hukum Islam Melalui Maqashid Syariah, PT. Mizan Pustaka, Bandung, 2015), hlm 35 . 
kebenaran, sedangkan kebenaran tidak akan bisa bercampur dengan yang salah, ini yang harus dipastikan tidak akan terjadi. Sesuai Pasal 30 Qanun KKR Aceh, maka hal-hal yang bisa direkonsiliasi adalah sesuatu yang tidak tergolong kedalam kejahatan/pelanggaran HAM. Bahkan, rekonsiliasi yang sudah terjadi sekalipun, jika terdapat pelanggaran HAM di dalamnya, tetap bisa ditindaklanjuti melalui mekanisme hukum (Pasal 31 ayat (4) Qanun KKRA).

Menjadi harapan bersama, dengan segala upaya untuk memperbaiki, menjaga perdamaian, serta mencipatakan keadilan yang berkelanjutan, semoga masalah-masalah di Aceh cepat selesai. Juga terhadap KKR Aceh khususnya, semoga ia tidak menjadi masalah yang masih tersisa pasca MoU Helsinki yang semestinya sudah tuntas beberapa tahun lalu. Tulisan ini juga diharap bermanfaat untuk dipertimbangkan, untuk menciptakan KKR Aceh yang diidamkan.

\section{Penutup}

Tulisan ini menemukan bahwa pembentukan KKR di Aceh didasarkan pada Pasal 229 UU No. 11 Tahun 2006 tentang Pemerintahan Aceh. Hanya saja, berdasarkan UU a quo, KKR Aceh disebut sebagai bagian dari KKR Nasional, sedangkan KKR Nasional belum terbentuk hingga sekarang. Terbentuknya KKR Aceh sepertinya memang kebutuhan mendesak. Keterdesakan itu yang kiranya menjadi faktor penyebab legal standing KKR di Aceh masih dapat dipertanyakan. Namun, hal ini juga nyatanya diabaikan. Pemerintah Aceh seakan tidak mau menunggu lama terbentuknya KKR Nasional. Dengan sepihak Qanun KKR Aceh akhirnya dibentuk. Anehnya, Pemerintah pusat juga tidak meributkan hal ini. Perdebatan yang muncul antara Aceh dan pusat justru menyasar pada persoalan yang kurang subtansial.

Selain itu, ditemukan pula bahwa konsep Kelembagaan KKR Aceh bersifat independen dan non-struktural dengan tujuan untuk memperkuat perdamaian, membantu tercapainya rekonsiliasi antara pelaku pelanggaran HAM dengan korban, dan merekomendasikan reparasi menyeluruh bagi korban pelanggaran HAM. KKR Aceh berasaskan keislaman, ke-Aceh-an, independensi, imparsial, nondiskriminasi, demokratisasi, keadilan dan kesetaraan, dan kepastian hukum. Sedangkan arah dari pembentukan KKR Aceh ini, sejalan dengan asas 
kemanusiaan yang adil dan beradab. Sebagai lembaga ajudikasi, KKR Aceh merupakan keniscayaan terhadap pengungkapan fakta yang selama ini dibiarkan. Ia juga merupakan satu sisi wajah penegakan HAM yang dilindungi oleh Konstitusi negara ini. Dengan kata lain, kemajuan hukum atau negara ini amat tergantung pada progresifitas KKR dalam pengungkapan kebenaran dan rekonsiliasi demi terlindunginya hak-hak dasar (fitrah) manusia. KKR Aceh juga memungkinkan pelanggaran HAM untuk ditindaklanjuti memalui mekanisme hukum.

\section{Daftar Pustaka}

\section{Buku}

Utama, Abraham, Jalan terjal Pengesahan Qanun KKR di Aceh, Koleksi Pusat Dokumentasi Elsam.

Hasjmy, Ali, Kebudayaan Aceh dalam Sejarah, Cetakan Kesatu, Penerbit Beuna, Jakarta, 1983.

Zein, Fajran, Rangkem (Ada KKR di Simpang KKA), Cetakan Kesatu, Aceh Institut Press, Banda Aceh, 2011.

Azhar, Haris, Geunap Aceh: Perdamaian Bukan Tanda tangan (Prospek Hukum KKR Aceh), Cetakan Kesatu, Aceh Institut Press, Banda Aceh, 2010.

Budiman, Hendra, Geunap Aceh: Perdamaian Bukan Tanda tangan (KKR dan Penyelesaian Masalah HAM), Cetakan Kesatu, Aceh Institut Press, Banda Aceh, 2010.

Hasan, Husaini, Dari RImba Aceh ke Stockhholm, Cetakan Kesatu, PT. Batavia Media Utama, Jakarta, 2015.

Bakti, Ikrar Nusa, Beranda Perdamaian Tiga Tahun pasca MoU Helsinki, Cetakan Kesatu, Pustaka Pelajar, Yogyakarta, 2008.

Syaukani, Imam dan A, Ahsin Thohari, Dasar-dasar Politik Hukum,Cetakan Keenam, PT. Raja Grafindo Persada, Jakarta, 2010.

Auda, Jasser, Membumikan Hukum Islam Melalui Maqashid Syariah, PT. Mizan Pustaka, Bandung, 2015.

MD, Moh. Mahfud, Politik Hukum di Indonesia, Cetakan Kesatu, Rajawali Press, Jakarta, 2009.

Amal, Taufik Adnan dan Samsu Rizal Panggabean, Poitik Syariat Islam, Cetakan Kesatu, Pustaka Alvabet, Jakarta, 2004. 
Setiadi, Tolib, Intisari Hukum Adat Indonesia, Cetakan Kedua, Penerbit Alfabeta, Bandung, 2009.

\section{Jurnal}

Heryati, Ulama dan Ulee Balang: Potret Revolusi Sosial di Aceh Tahun 1945 - 1946, Jurnal Historia, Vol. 3, No. 2, 2015.

Zainal, Suadi, Transformasi Konflik Acehdan Relasi Sosial -Politik di Era Desentralisasi. MASYARAKAT: Jurnal Sosiologi, Vol. 21, No. 1, Januari 2016.

\section{Koran}

Teuku Kemal Pasha, KKR dan Sisi Lain Luka, Kompas, 27 Juli 2016.

\section{Internet}

Komnas HAM Selidiki Pelanggaran HAM di Aceh, http:/ / www.hukumonline.com/ diakses pada tanggal 1 Agustus 2016.

“Terhambatnya Pembentukan KKR di Aceh", http://www.idlo.int/ diakses pada tanggal 4 Agustus 2016.

\section{Peraturan Perundang-Undangan}

UU Nomor 11 Tahun 2006 tentang Pemerintahan Aceh

UU Nomor 12 Tahun 2011 tentang Pembentukan Peraturan Perundang-Undangan

UU Nomor 27 Tahun 2004 tentang Komisi Kebenaran dan Rekonsiliasi

Qanun Aceh Nomor 17 Tahun 2013 Tentang Komisi Kebenaran dan Rekonsiliasi Aceh 